\title{
A Reality Check of Status Level of Worker against Skilled Worker Parameters for Bangladeshi Construction Industry
}

\author{
Shakil Ahmed ${ }^{1}$, Md. Ikramul Hoque ${ }^{2}$, Md. Hamidul Islam² ${ }^{2}$ and Mehrab Hossain ${ }^{1}$ \\ 1. Dept. of Building Engineering and Construction Management, KUET, \\ Khulna-9203, Bangladesh \\ 2. Dept. of Building Engineering and Construction Management, \\ KUET, Khulna-9203 Bangladesh \\ Email: ashakilmondol@gmail.com(Corresponding Author)
}

\begin{abstract}
Skilled worker is the main fuel to run the construction industry. To enhance construction management processes, worker is a vital factor. Lacking of skilled worker, have a huge negative impact on the construction cost, schedule and quality of construction work. Nine skilled worker parameter is setting out as Bangladesh perspective. The main objective of this study is to reality check of skilled worker parameter by evaluating the status level of worker against each parameter. The study was conducted by questionnaire survey. The questionnaire was designed by a comprehensive literature review and expert opinion. The data were collected through questionnaire survey among the construction workers in Bangladesh. The percentages of workers who satisfy the parameters of construction safety, materials, equipment and tools, labour law and BNBC are $19.35 \%$, $6.45 \%, 9.68 \%, 4.87 \%$ and $2.30 \%$ respectively. The workers having the professional training, minimum education and minimum working experience are $6.45 \%, 46.06 \%$ and $62.50 \%$ respectively. And the physically fit worker is found $62.25 \%$ in this study. Increased numbers of skilled workers boost the construction process and productivity that creates a very positive impact in the construction industry and enriches the national economy of Bangladesh.
\end{abstract}

Keywords: Construction Industry; Skilled Worker; Skilled Worker Parameter; Worker Status level; Bangladesh

\section{Introduction}

The construction industry has been known as the largest industry in the world. The construction sector dominates over a large portion of the world economy and GDP. Bangladesh is one of the emerging developing countries. The construction sector has contributed $7.88 \%$ GDP to the national economy of Bangladesh in recent year [1]. According to The Statistical Yearbook of Bangladesh 2016, about 3.33 million people are involved in construction sector directly or indirectly and the percentage rate withstands $5.6 \%$ of total national employees [2]. The construction industry has a significant role in contributing to the overall development of Bangladesh as it enhances the economy and generates a huge employment field. But it is one of the most densely populated countries in the world with 163 million population [3] and more than 1252 people live in per Square Kilometer [4]. For this huge size of the population, a huge in number but uncontrolled construction industries are growing quickly. This huge amount of uncontrolled construction industries are operated by the huge amount unskilled worker where the skilled worker is required. The skilled worker is who have professional training, have knowledge of safety, materials and equipment and execute them as standard process and procedures, the physical fitness and minimum level of education. This study 9 fundamental parameters of skilled worker are set by literature review and discussion with experts.

Workers are the major key to the successful running of the construction industry and skilled workers are the fuel of the construction. If high levels of construction output, as predicted by the authority have to be achieved, then this raises questions concerning how skilled worker shortage can be met [5]. Unskilled labour is the main factor of construction delays and cost overrun [6-8]. Shortage of skilled worker is one of the most significant causes of accident on construction site [9-10]. The shortage of skilled worker is the major factor that affects the quality of construction [11-13]. Construction delays, quality issues, cost overrun and safety related issues are the key elements that prevent the progress and success of a construction project. If anyone of these occurs, the whole project is undoubtedly going to be failed. This failed project obviously affect the individual, local and national economy and infrastructure improvement. So, the skilled worker is the most important parameter for the successful growth of our rising construction industry.

As it stands, the most crucial problem of construction industry is the shortage of skilled worker. About $82 \%$ of construction industry experiences the shortage of skilled workers [5]. Bangladesh faces the crisis of skilled

** Received 29 December 2017 ** 
worker more tremendously than other developing countries. A report indicates that about 31.32\% workers of construction sector in Bangladesh are skilled while rests are unskilled [6]. Bangladesh needs another 4 million skilled workers in construction sector by 2021 to meet the requirements of the growing economy [7]. To sustaining of the sustainable improvement of the construction industry as smoothly, skilled worker is the major required challenge to meet.

Thousands of workers are involved in construction industry in Bangladesh but most of them are unskilled. Skilled workers shortage is not due to the shortage of workers rather it is the shortage of adequately trained skilled and productive workers for certain jobs. So, it must be a way to turn the unskilled one to skilled but it has to find out by authority and government. To boost the industry, skilled worker is the most required parameter. Thus it is necessary to keep updated of the essential information of skilled worker in construction sector for monitoring and understanding the actual situation and take measure to overcome this unskilled worker issue. If the real scenario comes to light, it will be easier for the authority to take effective necessary steps to improve the quality and standard of workers in Bangladesh. For this, the study was conducted to find the real status level of construction worker against each parameters of skilled worker. This study will help to find out the causes and responsible elements for the lacking of sufficient skilled workers by analysis the worker status level against each set parameters of skilled worker in construction industry. It will also offer some suggestions which can play a vital role to decrease the crisis of skilled worker and turn the unskilled worker into skilled in Bangladesh.

\section{Research Methodology}

This study is undertaken in two perspective process. At first the parameters of skilled worker are set from discussion with experts and a comprehensive literature review. Figure 1 shows the entire process of conducting this study. The figure represent the step by step process of these study in a sequential order.

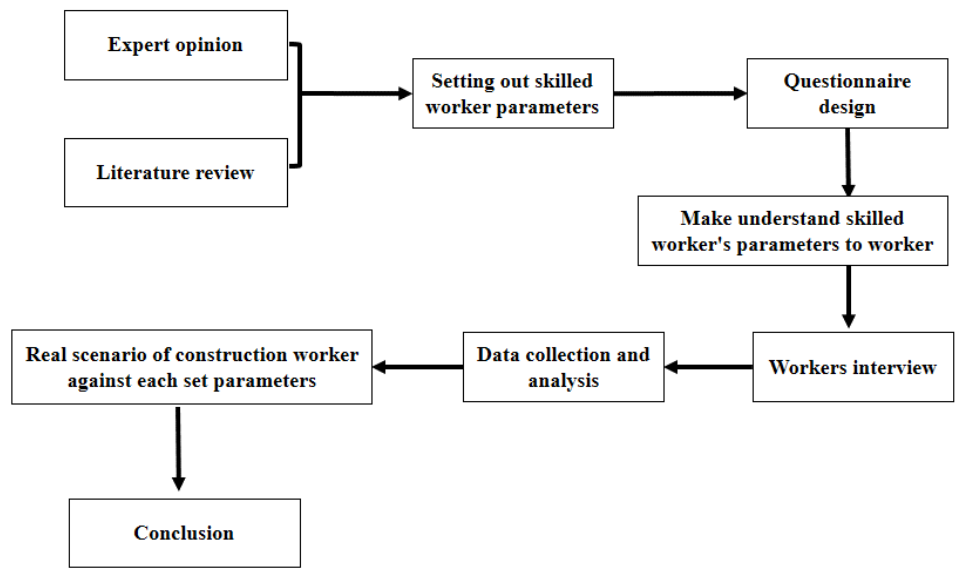

Figure 1: Flowchart of conducting the study

\section{Setting Out Parameters}

To conducting these study we are setting out the parameters of construction worker considering Bangladesh's socio-economic state, national labour condition, compatibility of construction industry and others issues. At first after a comprehensive literature review of journal paper, internet, newspaper and reports, a list of parameters shorting out initially from it. The reviewed literature are US Citizen and Immigration service [14], Alberta province official website, Canada [15], Construction Labour Contractors, Blog [16], S. E. Shoo et al. [17], Erin Tolley [18], USLegal [19], Manolo Abella [20], Breschi et al [21]. Some of the parameters are added, some of subtracted and finalized the set of parameters through a comprehensive discussion with an expert panel. The expert panel consists of high officials from Ministry of Labour and Employment (Bangladesh), Safety and Right (NGO work for worker safety and rights), Building Construction Labour Union Bangladesh (INSUB), experience Engineers, Architects, Project Managers and University Professors. After all the review and the discussion, the final set of parameters consisting 9 parameters of construction skilled worker in Bangladesh is coming out. The worker is considered skilled if he/she satisfy the 9 parameter. The 9 parameters are:

1) Construction related safety regulations in the workplace

2) Bangladesh National Building Code (BNBC) regulation

3) Bangladesh National Labour Law 
4) Construction materials related issues (merit, demerits, safety, standard use procedure and process, storage)

5) Construction equipment and tools related issue (standard operation procedure, safety, maintenance)

6) Professional training on related work

7) Minimum 2 years of working experience in related field

8) A good physical condition for performing his work

9) Primary education ( class 5)

\section{Questionnaire Design}

The research data were collected through a designed questionnaire. Each questionnaire was divided into 3 parts. Part I was about the general information about the respondent. Part II contained questions against each parameter of $1^{\text {st }}$ five parameters of skilled worker and the respondents dealt with the following 5 issues ; namely: (A) Known and followed, (B) Known but not followed, (C) Partially known and followed, (D) Partially known but not followed and (E) Unknown. Table 1 shows the part II of the questionnaire. In part III, respondents were requested to answer against each parameter of rest 4 parameters of skilled worker and the answer of the questionnaire can be given in 2 different ways namely (F) Yes and (G) No. Table 2 represents the part III of the questionnaire. Table-1 and Table 2 represent as an example of a surveyed questionnaire responded by a worker.

Table-1: Questionnaire part II

\begin{tabular}{|c|c|c|c|c|c|}
\hline \multirow[b]{3}{*}{ Questionnaire Topic } & \multicolumn{5}{|c|}{ Type of Answer } \\
\hline & $\mathbf{A}$ & $\mathbf{B}$ & $\mathrm{C}$ & $\mathbf{D}$ & $\mathbf{E}$ \\
\hline & $\begin{array}{l}\text { Known } \\
\text { and } \\
\text { followed }\end{array}$ & $\begin{array}{l}\text { Known but } \\
\text { not followed }\end{array}$ & $\begin{array}{l}\text { Partially known } \\
\text { and followed }\end{array}$ & $\begin{array}{c}\text { Partially } \\
\text { known but not } \\
\text { followed }\end{array}$ & Unknown \\
\hline Safety regulation & & & $\sqrt{ }$ & & \\
\hline BNBC regulation & & $\sqrt{ }$ & & & \\
\hline Labour law & & & & $\sqrt{ }$ & \\
\hline $\begin{array}{l}\text { Construction materials } \\
\text { related issue }\end{array}$ & & & & & $\sqrt{ }$ \\
\hline $\begin{array}{c}\text { Construction equipment } \\
\text { and tools related issue }\end{array}$ & $\sqrt{ }$ & & & & \\
\hline
\end{tabular}

Table 2: Questionnaire part III

\begin{tabular}{|c|c|c|}
\hline \multirow{2}{*}{ Questionnaire Topic } & \multicolumn{2}{|c|}{ Type of Answer } \\
\cline { 2 - 3 } & Fes & G \\
\cline { 2 - 3 } & & $\sqrt{ }$ \\
\hline Work related training & $\sqrt{\mid}$ \\
\hline Working experience (minimum 2 years) & $\sqrt{ }$ \\
\hline Physically fit & & $\sqrt{ }$ \\
\hline Education (minimum class 5) & & \\
\hline
\end{tabular}

\section{Data Collection}

The necessary data were collected through the questionnaire survey among the construction workers by visiting construction sites, labour unions, labour welfare trust, and government agencies and so on. A total 87 sets of questionnaire were distributed among the workers.71 sets were returned of the 87 sets of questionnaire, which is $82 \%$ of total distributed sets.

\section{Data Analysis}

Table 3 represents the demographic characteristics of the respondents. 
Table 3: Demographic characteristics of respondents

\begin{tabular}{|c|c|c|}
\hline Demographic Characteristics & Frequency & Percentage, \% \\
\hline \multicolumn{3}{|c|}{ Sex } \\
\hline Male & 52 & 73 \\
\hline Female & 19 & 27 \\
\hline \multicolumn{3}{|c|}{ Age } \\
\hline$\leq 20$ years old & 15 & 21 \\
\hline 21-30 years old & 26 & 37 \\
\hline 31-40 years old & 17 & 24 \\
\hline$\geq 40$ years old & 13 & 18 \\
\hline \multicolumn{3}{|c|}{ Location } \\
\hline Dhaka Division & 18 & 25 \\
\hline Rajshahi and Rangpur Division & 11 & 15 \\
\hline Chittagong Division & 13 & 18 \\
\hline Sylhet Division & 8 & 11 \\
\hline Khulna and Barisal Division & 21 & 31 \\
\hline \multicolumn{3}{|c|}{ Project Type } \\
\hline Building & 29 & 41 \\
\hline Infrastructure & 20 & 28 \\
\hline Electrical and mechanical & 14 & 20 \\
\hline others & 8 & 11 \\
\hline
\end{tabular}

The number of workers are categorized in five group's answers against each of the question in part II and two groups in part III of the questionnaire. The following equation is used to calculate the Percentage of workers in percentage:

$$
\mathrm{W}=\frac{Q X 100}{N}
$$

In above equation (1), ' $W$ ' indicates the percentage of workers who choose " $P$ " type answer. Here " $Q$ " is the total number of worker who choose "P" type answer (in equation-1 "P" is a symbol used for indicating any type of answer, for this study P = A, B, C, D, E or F type answer) and ' $N$ ' means total number of workers (for this study $\mathrm{N}=71$ ).

\section{Result And Discussion}

The real status level against the 9 major parameters of skilled workers in construction sector is analyzed by the collected data through the questionnaire survey. What type and how much workers have knowledge about various construction essentials and practice regulations in the working site is shown in Table 4 and Table 5.

Table 4: Statistics of worker against skilled worker parameter at questionnaire part II

\begin{tabular}{|c|c|c|c|c|c|}
\hline Question/Answer & $\begin{array}{c}\text { Known and } \\
\text { followed }\end{array}$ & $\begin{array}{c}\text { Known but } \\
\text { not followed }\end{array}$ & $\begin{array}{c}\text { Partially } \\
\text { known and } \\
\text { followed }\end{array}$ & $\begin{array}{c}\text { Partially known } \\
\text { but not followed }\end{array}$ & Unknown \\
\hline Safety regulation & $9.35 \%$ & $15.58 \%$ & $2.80 \%$ & $26.24 \%$ & $46.03 \%$ \\
\hline BNBC regulation & $2.30 \%$ & $5.88 \%$ & $16.13 \%$ & $20.08 \%$ & $55.61 \%$ \\
\hline Labour law & $4.87 \%$ & $14.65 \%$ & $2.50 \%$ & $5.45 \%$ & $72.53 \%$ \\
\hline $\begin{array}{c}\text { Construction materials } \\
\text { related issue }\end{array}$ & $6.45 \%$ & $11.00 \%$ & $24.93 \%$ & $31.70 \%$ & $25.92 \%$ \\
\hline $\begin{array}{c}\text { Construction equipment } \\
\text { and tools related issue }\end{array}$ & $9.68 \%$ & $23.43 \%$ & $32.26 \%$ & $7.55 \%$ & $27.08 \%$ \\
\hline
\end{tabular}


Table 5: Statistics of worker against skilled worker parameter at questionnaire part III

\begin{tabular}{|c|c|c|}
\hline Question/Answer & Yes & No \\
\hline Work related training & $6.45 \%$ & $93.55 \%$ \\
\hline Working experience (minimum 2 years) & $62.50 \%$ & $37.50 \%$ \\
\hline Physically fit & $69.25 \%$ & $30.75 \%$ \\
\hline Education (minimum class 5) & $46.06 \%$ & $53.94 \%$ \\
\hline
\end{tabular}

\subsection{Construction safety}

Figure 2 shows that $9.35 \%$ of the workers properly know and $2.80 \%$ of the workers partly know the construction safety and both groups of workers practices the regulation at working sites against knowledge for safety. $15.58 \%$ of the workers know and $26.24 \%$ of workers partially know the regulation of construction safety but they don't practice the regulation at working sites. Almost half of the total workers about $46.03 \%$ are not aware of construction safety regulations and know nothing about construction health and safety. They don't take any safety measures during work.

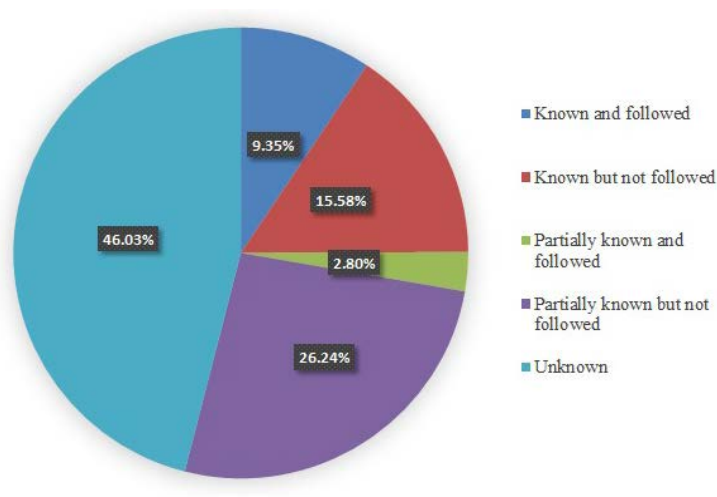

Figure 2: Percentage of worker against construction safety related parameter

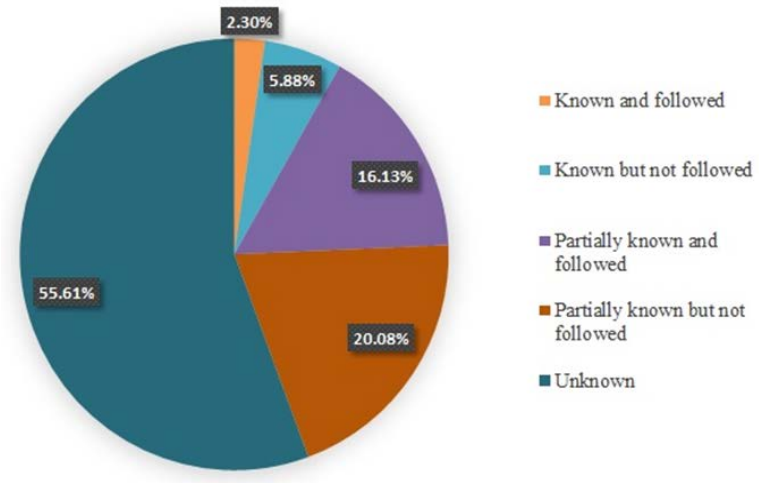

Figure 3: Percentage of worker against BNBC related parameter

\subsection{BNBC}

Figure 3 indicates that more than half portion of the workers in construction sectors do not know about the regulations and guidance of BNBC and the amount is $55.61 \%$. Only $2.30 \%$ of workers properly know while $16.13 \%$ know partially and they follow and practice BNBC guidance and regulations at working site. Other $5.88 \%$ of workers know and $20.08 \%$ of workers partially know the regulations and guidance of BNBC but they do not follow and practice at working sites.

\subsection{National labour law}

Most of the Bangladeshi construction workers are not aware of the national labour laws. Figure 4 presents the current culture and attitude of construction worker toward national labour law in Bangladesh. A huge portion of construction workers about $72.53 \%$ are totally unaware and don't know about the national labour laws/acts. Only 4.87\% purely know while another $2.50 \%$ partly know and they follow the labour laws in their professional field. Another $14.65 \%$ know and $5.45 \%$ partially know but they do not follow or practice the labour laws.

\subsection{Construction materials}

Construction materials are the most important and obvious things to perform the construction project. There are no materials there is no construction. But most of the construction materials belong some demerits with it. Workers always work with the material, so it is very necessary to the worker to know all the material's properties and standard use procedures. But in Bangladesh worker are mostly unaware of this issue. Figure 5 indicates that $6.45 \%$ workers purely know while $24.93 \%$ workers partially know about construction materials, their demerits, standard use procedure and related safety issues. Also, they follow and practice these concern at the workplace. A quarter portion of $25.92 \%$ construction workers is totally unaware. Rest of $11.00 \%$ are known and $31.70 \%$ are partly known but they do not follow or practice at workplace. 


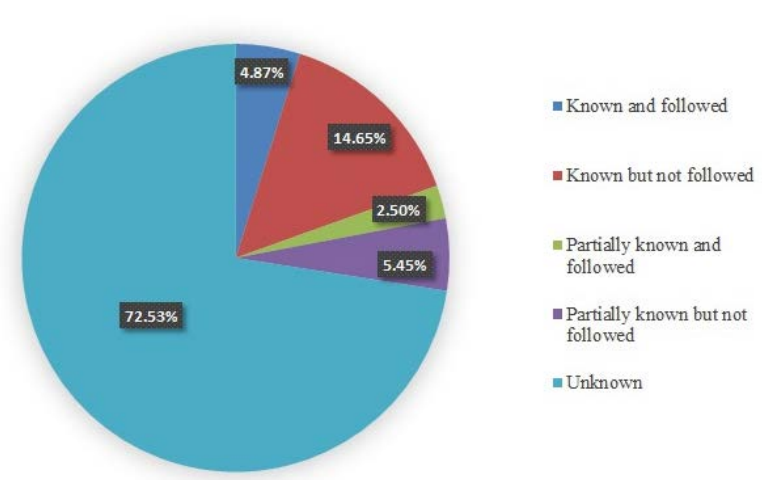

Figure 4: Percentage of worker against Labour law related parameter

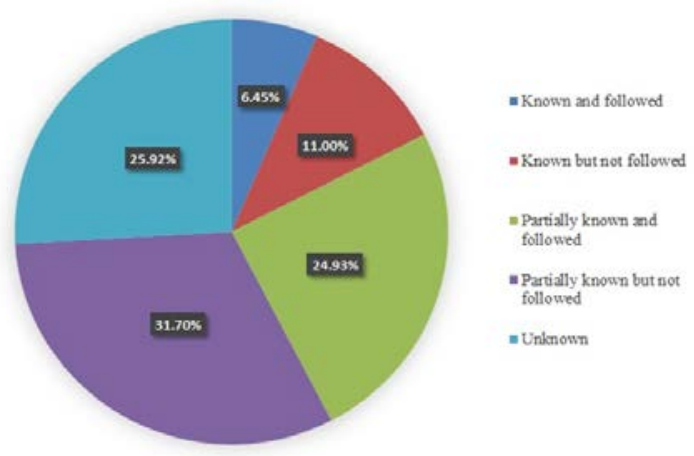

Figure 5: Percentage of worker against construction materials related parameter

\subsection{Construction equipment and tools}

A vast amount of construction worker in Bangladesh totally unaware of the standard procedure of using construction equipment and tools, related safety measure of equipment and tools and training. From figure 6 it could be seen the status level of the worker against this parameter. It indicates that $9.68 \%$ workers purely know while 32.26\% workers partially know the standard working procedure and related safety and they practice them at work sites. Another $23.43 \%$ workers know and $7.55 \%$ workers partially know but they practice at work sites. Rest of the workers $27.08 \%$ are unaware of this parameter.

\subsection{Work related training}

Work related training is a mandatory practice for any profession [22]. But in Bangladesh, training to construction worker related of his work is a nightmare [23]. How poor condition of worker training in Bangladesh is appeared clearly in figure 7 . A just $6.45 \%$ of total construction workers get occupational training and rest of the $93.55 \%$ worker don't get any training related to their work. This untrained worker force is could harmful to construction project in many ways.

\subsection{Working experience}

Working experience is one of the major parameter to become a skilled worker. In Bangladesh, a lot of newcomers involve in construction work without any expertise. From figure 8 it is shown percentage of construction workers who have minimum two years working experience or not. A favorable amount of $62.50 \%$ workers have experience and another $37.50 \%$ worker do not have two years working experience for in this study. This amount is quite good than other parameters.

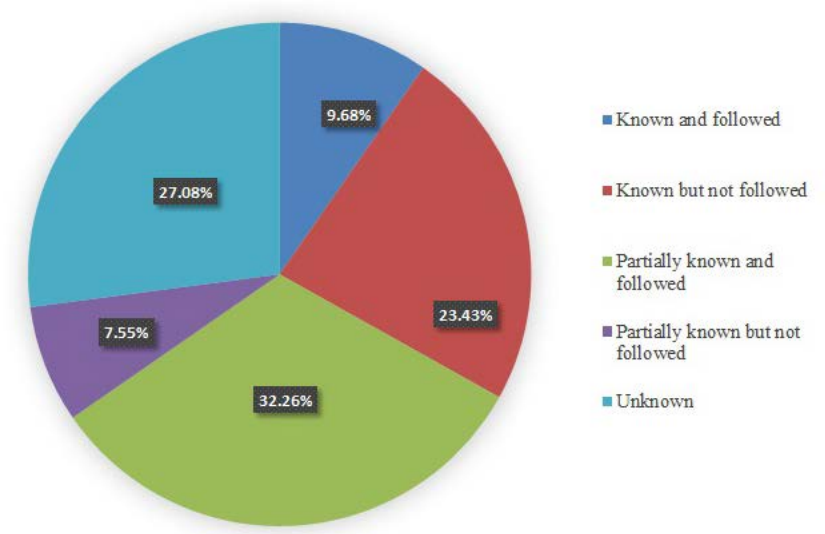

Figure 6: Percentage of worker against construction equipment and tools related parameter

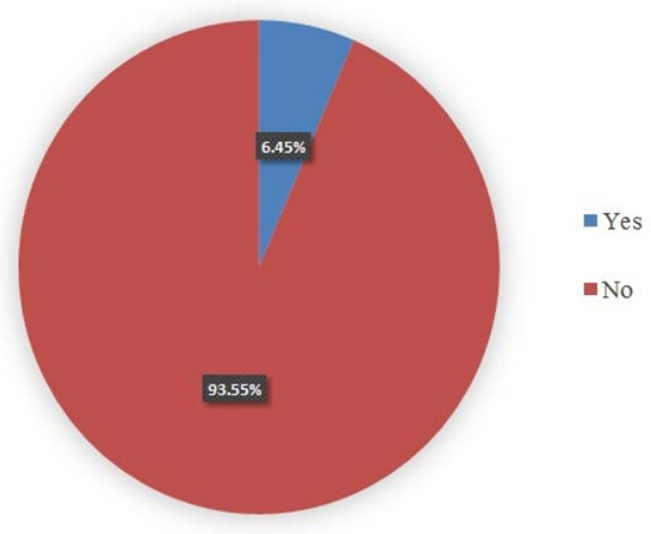

Figure 7: Percentage of worker against occupational training related parameter

\subsection{Physical condition}

Worker are the main fuel of including construction industry. And physically fit worker are undoubtedly a valuable asset to the company. A big portion of worker found with low to high impact health issues in this study. From figure 7 it has been seen that $69.25 \%$ workers are physically fit and other $30.75 \%$ workers are appeared 
with unhealthy physical condition. This unhealthy portion of worker play a role of problem creator rather than an asset.

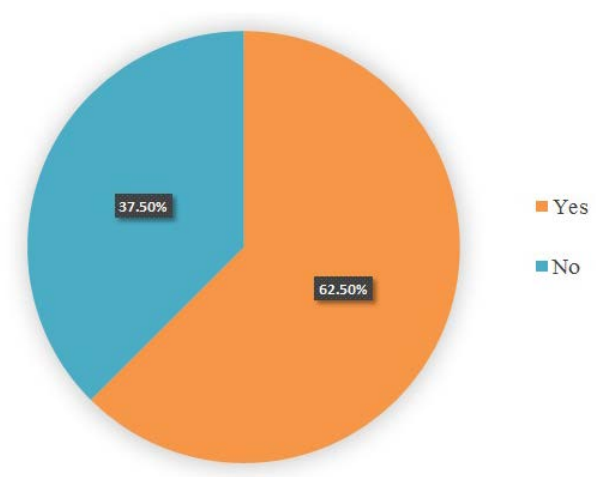

Figure 8: Percentage of worker against working experience related parameter

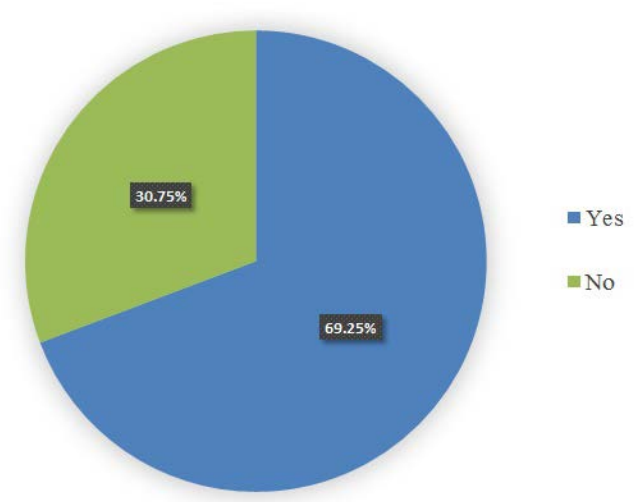

Figure 9: Percentage of worker against physically sound related parameter

\subsection{Education}

A minimum level of education is necessary to the worker in any sector of work. The minimum level is set as class five for Bangladeshi workers in this study. In this study the worker proportion is clearly displayed against the minimum education, the parameter of skilled worker in construction industry. Figure 10 indicates that only $46.06 \%$ workers are educated as required level (class five) and other $53.94 \%$ workers are uneducated. This uneducated portion may bring threats to construction project in many ways.

\section{Conclusion And Recommendation}

Almost half of the total workers are unaware of construction safety measure hence they are falling into accidents every day at a high rate. A little portions of workers know safety regulation and know how to take safety measures but they don't. To improve this situation, necessary steps should be taken to provide the workers with proper training by the authority. Authority should make arrangement for teaching the basic idea of safety measures, health and hygiene, risk management and other fundamental issues of construction health and safety. A large portion, which is more than half of the construction workers in Bangladesh do not know the BNBC and Labour Laws. Another other small portion who knows the code and laws but do not follow and practice them at work sites. Governmental agencies and Bangladesh Employers Federation have to be strict in order to implement the regulations at every construction projects. Around one-fourth of construction workers are unaware of safety and standard procedures of construction materials and construction equipment. Half of the workers completely or partially have the knowledge of the guidelines for equipment and materials but do not follow and do not practice them in working fields. Training for workers has to be arranged to provide the opportunity to the workers to learn and to be expert at his work. Technical supervision is necessary at working place to guide and monitor them during working period and it is an effective way to improve the level of expertise and skill of workers.

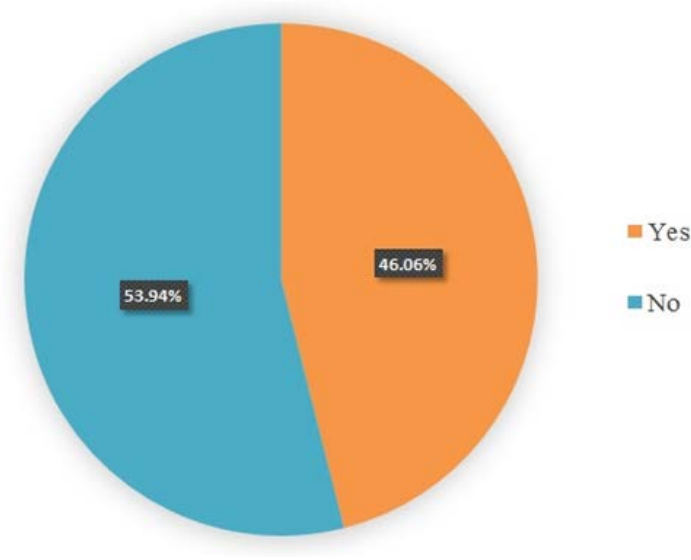

Figure 10: Percentage of worker against education related parameter

Other criteria of skilled workers are described as part III of the questionnaire. Almost all the workers of construction sectors in Bangladesh do not have occupational training. A few workers get training based on the 
working field but are in the worst condition. Authority should understand the benefits of trained workers and bad effects of untrained workers on the project and thus they should provide the effective training program to their workers. Minimum working experience and a minimum level of education are the key parameters of skilled workers. Around half of the construction workers do not have minimum working experience and a minimum level of education. The government must take steps to educate all people at a minimum level. Another parameter is physically fit worker as they are the power of construction industry. A big portion of workers is found fit in this study while rests of the workers are found unfit during the time of surveying. Authority should give attention to take care of their unfit and sick worker; providing first aid, medical treatment and psychological counseling. Also, it is important to provide them with special leaves and momentary allowance for medical purpose.

For the long term benefits of construction industry respective authorities and the government agencies are have to understand the real status of worker against each parameters and take measure in best effective ways to the newcomers acknowledgement who entering the industry as skilled and to existing unskilled worker turn into skilled.

\section{Acknowledgement}

The authors would like to thank the Department of Building Engineering and Construction Management, KUET, Khulna-9203 Bangladesh for technical supports. The authors also would like to thank the workers who help by giving essential response to the questionnaire.

\section{References}

[1] B.B.O. STATISTICS, Statistical Yearbook of Bangladesh, 2016, Dhaka, Bangladesh, 2016.

[2] B.S. Yearbook, Statistical Division, Ministry of Fi-Nance and Planning, Government of Bangladesh, various issues (2015).

[3] P.R. Bureau, 2016 world population data sheet with a special focus on human needs and sustainable resources, www.worldpopdata.org, 2017, p. 3.

[4] Word Bank, World Development Indicators United Nations Population Division. World Population 2017.

[5] A. Agapiou, A.D. Price, R. McCaffer, Planning future construction skill requirements: understanding labour resource issues, Construction Management and Economics 13(2) (1995) 149-161.

[6] Y. Frimpong, J. Oluwoye, L. Crawford, Causes of delay and cost overruns in construction of groundwater projects in a developing countries; Ghana as a case study, International Journal of project management 21(5) (2003) 321-326.

[7] P. Koushki, K. Al-Rashid, N. Kartam, Delays and cost increases in the construction of private residential projects in Kuwait, Construction Management and Economics 23(3) (2005) 285-294.

[8] N.R. Mansfield, O. Ugwu, T. Doran, Causes of delay and cost overruns in Nigerian construction projects, International Journal of Project Management 12(4) (1994) 254-260.

[9] T.S. Abdelhamid, J.G. Everett, Identifying root causes of construction accidents, Journal of construction engineering and management 126(1) (2000) 52-60.

[10] A. Suraji, A.R. Duff, S.J. Peckitt, Development of causal model of construction accident causation, Journal of construction engineering and management 127(4) (2001) 337-344.

[11] A. Enshassi, S. Mohamed, S. Abushaban, Factors affecting the performance of construction projects in the Gaza strip, Journal of Civil engineering and Management 15(3) (2009) 269-280.

[12] M. Abas, S. Khattak, I. Hussain, S. Maqsood, I. Ahmad, Evaluation of Factors affecting the quality of construction projects, Technical Journal, University of Engineering and Technology (UET) Taxila, Pakistan 20(2) (2015) 115-120.

[13] A.P. Chan, D. Scott, A.P. Chan, Factors affecting the success of a construction project, Journal of construction engineering and management 130(1) (2004) 153-155.

[14] D.o.H. Security, Employment-Based Immigration, National Customer Service Center, NY, 2018.

[15] C. Alberta, Skilled Worker Criteria, 2018. (Accessed 6 march 2018).

[16] CLC, Skilled Workers In High Demand, http://constructionlabour.com/skilled-workers/, 2018.

[17] S.E. Khoo, P. McDonald, C. Voigt-Graf, G. Hugo, A global labour market: Factors motivating the sponsorship and temporary migration of skilled workers to Australia, International Migration Review 41(2) (2007) 480-510.

[18] E. Tolley, The skilled worker class: Selection criteria in the Immigration and Refugee Protection Act, Canadian Issues (2003).

[19] UsLegal, Skilled Work Law and Legal Definition, 2011. https://definitions.uslegal.com/s/skilled-work/. (Accessed 8 july 2017). 
[20] M. Abella, Global competition for skilled workers and consequences, Competing for global talent (2006) 11-32.

[21] S. Breschi, F. Lissoni, Mobility of skilled workers and co-invention networks: an anatomy of localized knowledge flows, Journal of economic geography 9(4) (2009) 439-468.

[22] X. Dong, J.W. Platner, Occupational fatalities of Hispanic construction workers from 1992 to 2000, American journal of industrial medicine 45(1) (2004) 45-54.

[23] V.K. Biswas, Socio-Economic Background of Construction Workers: A Study on Dhaka City, World Vision Research Journal 8(1) (2014) 82-91. 